\title{
The Social Science History Association: The Network on Workers and Industrialization
}

\author{
Charles Stephenson \\ State University of New York, Brockport
}

The annual business meeting of the Network on Workers and Industrialization was held at the Social Science History Association Convention in Nashville last October. A number of interesting and significant decisions were reached there.

The Network first offered a strong vote of thanks to the Executive Board members whose terms expired in 1981: Ronald Aminzade (Sociology-Europe, University of Wisconsin, Madison), Michael Hanagan (History-Europe, Vanderbilt University), and Thomas Dublin (History-U.S., University of California, San Diego). The addition of three new members was authorized: Richard Barett (Sociology-Asia, University of Illinois, Chicago Circle), Florencia Mallon (History-Latin America, University of Wisconsin at Milwaukee), and Helen I. Safa (Anthropology-Latin America, Univ. of Florida). Continuing members of the Board are: (term expiring in 1982) David Montgomery (History-U.S., Yale University), Bo Ohngren (History-Europe, Upssala University), and Joan Scott (History-Europe and U.S., Brown University); (term expiring in 1983) Susan Hirsch (History-U. S., Northwestern University), Martin Murray (Sociology-Africa, State University of New York, Binghamton), and Sharon Stichter (SociologyAfrica, University of Massachusetts, Boston).

Members of the Network authorized the Chair to establish independent, taxexempt status for the organization. This was deemed necessary in order to facilitate collection of dues, which were authorized at the $\$ 4.00$ level, and other such activities. The Network will continue its affiliated status with the Social Science History Association.

Network members also authorized the formation of several area or thematic interest groups which will concentrate on increasing connections and the flow of information among those involved, and will produce several kinds of materials, including bibliographies, course outlines, and perhaps collections for Networksponsored publications. A Coordinator for these groups will be appointed. Anyone 
interested in participating in and helping to establish these groups should contact the Network Chair, Charles Stephenson, at the Department of History, SUNY College at Brockport, Brockport, NY 14420.

Michael Hanagan agreed to serve as coordinator for programs for the next SSHA meeting, which is scheduled for Bloomington, Indiana. The Network also has been asked to encourage organized submissions from its members to other meetings, especially the North American Labor History Conference, scheduled for Detroit next October, and the Southern Labor History Conference. The Network might well be able to make a contribution by undertaking such suggestions on a regular basis, and we should discuss this possibility.

The Network has arranged for a number of periodicals to offer discounts to its members. Such journals as History Workshop Journal, International Review of Social History, International Journal of Women's Studies, Social Science Quarterly, Latin American Perspectives, Antipode: A Radical Journal of Geography, Jump Cut, The British Journal of Sociology, and a number of others are included, and others are being added to the list. Full information and coupons will be available in the next occassional Newsletter on Workers and Industrialization.

The Network offered seven sessions at the SSHA meetings:

Comparative Perspectives on Hegemony and Social Management

The Development of the Working Class in Asia

Creating a Proletariat: Labor Recruitment and Control in Latin America

Women Workers and Socialists, 1880-1920: Reluctant or Inevitable Feminists?

Family Formation, Women Workers, and the Emergence of the Industrial Working Class in France

Protest, Resistance and Social Control: Industrialization in the Piedmont South Film as History, History as Film: The Moulders of Troy

Attendance at the panels varied, but interest was high in each of them. The crossnational and multidisciplinary nature of most Network sessions contributed to the hearty exchange which characterized them. Unfortunately, some Network panels suffered from the same problem of "cancellation syndrome" that plagued other sessions at the conference. A number of panels found participants-chairs, commentators, and paper-givers-cancelled at the last minute and indeed, one session, "Themes in Labor History in Europe and the United States," had to be cancelled when only the chair and a commentator appeared! The Network Chair has written next year's SSHA president concerning this situation, suggesting a deadline for paper submission to be adhered to strictly_produce or be cancelled! Members of Network panels must be particularly observant of deadlines and faithful to commitments which have been made.

The Network is growing and is consolidating its activities, and looks forward to a busy year ahead and to meeting again this fall in Indiana. 